\title{
Peran Regulasi Diri dan Konformitas terhadap Perilaku Berkendara Berisiko pada Remaja
}

\author{
Happy Virgina Puspa Nirmala1 \& Bhina Patria ${ }^{2}$ \\ 1,2Fakultas Psikologi Universitas Gadjah Mada
}

\begin{abstract}
There are a number factors that contribute to the traffic accident at adolescents. One of them is the implementation of risky driving behaviour. The psychological factros that can be the predictors of risky driving behaviour are self-regulation and conformity. The aim of this research is to identify the factors' role of risky driving behaviour at young novice drivers. The study involved adolescents aged 16 to 18 who were eligible subjects of the study. This study uses an adaptation of the Driving Behaviour Quetionnaire (DBQ) and The Czech Self-Regulation Quetionnaire (SRQ-Cz). Hypotheses of this research is that self-regulation and conformity have contribution to the risky driving behaviour. Regression analysis shows that self-regulation and conformity $13.5 \%$ contribute to the risky driving behaviour simultaneously, $6.5 \%$ is from self-regulation and $7 \%$ from conformity $(\mathrm{F}=6,29 ; \mathrm{p}<0,05)$. Analysis also shows that self-regulation has negative correlation to the risky driving behaviour where as conformity has positive correlation to the risky driving behaviour.
\end{abstract}

Keywords: adolescents, traffic accident, risky driving behaviour, selfregulation,conformity

\begin{abstract}
Abstrak. Tingginya angka kecelakaan lalu lintas pada usia remaja disebabkan oleh diterapkannya perilaku berkendara berisiko. Perilaku tersebut dipengaruhi oleh faktorfaktor psikologis tertentu. Penelitian ini bertujuan untuk mengetahui peran regulasi diri dan konformitas sebagai faktor psikologis yang dapat memprediksi perilaku berkendara berisiko pada remaja. Penelitian melibatkan remaja berusia 16 hingga 18 tahun yang memenuhi syarat subjek penelitian. Penelitian ini menggunakan alat ukur adaptasi dari Driving Behaviour Quetionnaire (DBQ) dan The Czech Self-Regulation Quetionnaire (SRQ-Cz). Hipotesis yang diajukan adalah regulasi diri dan konformitas berperan bersama-sama terhadap perilaku berkendara berisiko. Hasil analisis regresi menunjukkan regulasi diri dan konformitas bersama-sama memberikan perannya sebesar $13,5 \% \quad(F=6,29 ; \quad p<0,05)$ terhadap dilakukannya perilaku berkendara berisiko. Regulasi diri memberikan sumbangan sebesar 6,5\%, sedangkan konformitas sebesar 7\%. Terkait dengan hubungannya, regulasi diri berhubungan negatif dengan perilaku berkendara berisiko. Sebaliknya, konformitas berhubungan positif dengan perilaku berkendara berisiko.
\end{abstract}

Kata kunci: remaja, kecelakaan lalu lintas, perilaku berkendara berisiko, regulasi diri, konformitas.

${ }^{1}$ Korespondensi mengenai isi artikel ini dapat disampaikan melalui: happy.virgina.p@mail.ugm.ac.id

2Ataumelalui:patria@ugm.ac.id 
Pada tahun 2002, World Health Organization (WHO) melakukan penelitian tentang kejadian kecelakaan lalu lintas di seluruh dunia. Hasil penelitian waktu itu menyatakan bahwa lebih dari $30 \%$ anak dan remaja di seluruh dunia mengalami cedera hingga kematian akibat kecelakaan lalu lintas (Toroyan \& Peden, 2007). Dalam laporan penelitiannya, WHO memprediksi akan adanya peningkatan angka cedera, disabilitas, hingga kematian akibat kecelakaan lalu lintas. Prediksi tersebut tidak lepas dari fakta di lingkungan yang memperlihatkan pesatnya pertumbuhan moda transportasi di seluruh dunia.

Prediksi WHO terbukti oleh penelitian tahun 2008. Pada tahun 2009, WHO kembali merilis data tentang kecelakaan lalu lintas yang terjadi setahun sebelumnya. Dalam laporannya, WHO menyatakan bahwa setiap tahunnya, sekitar 1,2 juta orang mengalami kecelakaan lalu lintas. Kecelakaan tersebut telah melukai setidaknya 20 hingga 50 juta orang di seluruh dunia (WHO, 2009). Berdasarkan fakta tersebut, terdapat satu hal yang menjadi perhatian khusus dalam dunia kesehatan. Perhatian khusus itu yakni bahwa dari sekian puluh juta korban kecela-kaan lalu lintas, sebagian besar adalah mereka yang berada di kelompok usia anak dan remaja. Kecelakaan lalu lintas telah memberi sumbangan terbesar atas tinggi-nya angka kematian di usia 5 hingga 24 tahun (Ramisetty-Mikler \& Almakadma, 2016).

Anak dan remaja menjadi kelompok yang paling rentan mengalami kecelakaan lalu lintas. Penelitian di Amerika Serikat menyebutkan bahwa remaja usia 16-19 tahun menduduki posisi tertinggi sebagai kelompok korban kecelakaan lalu lintas (Ragin, 2015). Data serupa juga ditemukan di Australia. Pada tahun 2010, terdata sebanyak $26 \%$ pengemudi usia 17-25 tahun di Australia tewas akibat kecelakaan lalu lintas (National Road Safety Council, 2012 dalam Vassallo, Lahausse, \& Edwards, 2015). Sementara itu, dalam penelitian global oleh WHO, disimpulkan bahwa kecelakaan lalu lintas menjadi penyebab utama kematian di usia muda (WHO, 2009). Data kematian anak dan remaja akibat kecelakaan lalu lintas itu berlaku di seluruh dunia. Prevalensi tertinggi terdapat di negara-negara dengan level ekonomi rendah dan di negara-negara berkembang (Toroyan, 2015).

Sementara itu, kelompok-kelompok yang rentan mengalami kecelakaan lalu lintas antara lain pejalan kaki, pesepeda, pengendara motor, dan penumpang kendaraan umum (Toroyan \& Peden, 2007). Berdasarkan laporan WHO 2015, pengguna sepeda motor (roda dua maupun roda tiga) menjadi kelompok yang paling rentan mengalami kecelakaan lalu lintas (Toroyan, 2015). Hal itu disebabkan oleh desain kendaraan roda dua yang minim perlin-dungan dan pengamanan (Ragin, 2015).

Tingginya angka cedera dan kematian akibat kecelakaan lalu lintas tidak lepas dari perilaku individu ketika berlalu lintas. Pada umumnya, kecelakaan lalu lintas terjadi karena individu melakukan perilaku berisiko ketika berkendara (Ragin, 2015). Perilaku berkendara berisiko diwujudkan dalam berbagai bentuk seperti bekendara dengan kecepatan tinggi, berkendara dalam kondisi mabuk, berkendara tanpa lisensi, tidak digunakannya helm, sabuk penga-man, modifikasi kendaraan, pelanggaran ramburambu, dan lain-lain (Ragin, 2015; Toroyan, 2015).

Perilaku berkendara berisiko merupakan perilaku yang dapat membahayakan individu pengendara dan individu lain yang ada di sekitarnya. Perilaku berisiko menjadi sesuatu yang memprihatinkan apabila sudah biasa dilakukan sejak 
remaja. Menurut Ragin (2015), perilaku berisiko yang dilakukan ketika remaja dapat dibawa hingga dewasa. Perilaku berisiko dapat menjadi kebiasaan berulang. Pengulangan perilaku tersebut terjadi karena individu merasa terbiasa mendapatkan keuntungan ketika melakukannya.

Melakukan perilaku berisiko atau perilaku aman ketika berkendara adalah suatu pilihan bagi remaja. Briem, Radeborg, Salo, dan Bengston (2004) memaparkan bahwa partisipasi untuk berkendara secara aman atau berisiko melibatkan keteram-pilan kognitif. Keteram-pilan kognitif terse-but meliputi tiga hal, yaitu persepsi, antisi-pasi, dan pengambilan keputusan. Kete-rampilan kognitif lain yang melingkupi berbagai macam proses mental ketika berkendara adalah regulasi diri (self-regulation).

Perilaku remaja ketika berkendara tidak hanya disebabkan oleh kondisi internal dirinya, akan tetapi juga pengaruh lingkungan. Pengaruh lingkungan mendorong terjadinya proses mental yang kompleks. Pengaruh lingkungan yang dapat dialami oleh pengendara antara lain: peraturan lalu lintas, keberadaan penumpang, perilaku penumpang, dan perilaku pengendara lain.

Pengaruh lingkungan dapat dihadapi melalui proses mental berupa regulasi diri. Baumeister dan Bushman (2014) menyatakan bahwa regulasi diri merupakan salah satu keterampilan kognitif yang dapat digunakan untuk menghadapi pengaruh lingkungan. Secara luas, regulasi diri didefinisikan sebagai kemampuan untuk memantau dan memodulasi kognisi, emosi, dan perilaku yang digunakan untuk mencapai suatu tujuan (Berger, 2011). Kemampuan tersebut juga digunakan untuk menyesuaikan diri dengan pengaruh kognitif dan sosial pada kondisi tertentu (Berger, 2011).
Berdasarkan pengertian tersebut, terlihat bahwa regulasi diri individu berkaitan dengan pengaruh-pengaruh yang diterima oleh individu. Dalam konteks lalu lintas, perilaku berisiko yang dilakukan oleh remaja dapat terjadi karena adanya pengaruh sosial yang kuat. Scott-Parker, Watson, King, dan Hyde (2014) mengatakan bahwa remaja mendapatkan pengaruh sosial melalui proses belajar sosial (social learning) dari teman sebaya. Salah satu contoh social learning pada remaja adalah mempelajari perilaku berlalu lintas dari teman sebaya. Melalui proses belajar itu, remaja dapat menirukan perilaku teman sebaya dan menjadikannya sebagai penguat dalam berperilaku, berkendara aman atau berisiko (ScottParker dkk., 2014).

Pengaruh sosial dapat terjadi dalam berbagai macam bentuk (Scott-Parker dkk., 2014). Salah satu bentuk pengaruh sosial yang banyak terjadi pada individu adalah konformitas. Konformitas merupakan upaya menirukan hal-hal yang dilakukan oleh orang lain. Pada remaja, konformitas dapat terjadi ketika ia meniru atau mengubah perilakunya agar mirip atau serupa dengan yang dilakukan oleh kelompok teman sebayanya (Myers, 2010). Proses meniru atau mengubah perilaku tersebut bisa terjadi karena adanya unsur tekanan dari orang lain atau kelompok (Franzoi, 2009).

Tekanan dari kelompok teman sebaya dapat menyebabkan remaja berkendara berisiko. Hal ini didukung oleh penelitian Ragin (2015) yang membuktikan bahwa teman sebaya mampu memengaruhi remaja untuk berkendara tidak aman. Remaja mengalami peningkatan risiko kecelakaan sebesar $40 \%$ ketika ditemani oleh seorang teman sebaya. Risiko kecelakaan meningkat dua kali lipat ketika remaja ditemani oleh dua orang teman sebayanya. Risiko semakin 
besar ketika remaja bersama tiga atau lebih teman sebaya. Risiko kecelakaan itu terjadi karena teman sebaya menjadi distraktor bagi remaja yang sedang mengendarai kendaraannya (Ragin, 2015). Distraksi dari teman sebaya berbentuk anjuran, perintah, atau ajakan untuk melakukan sesuatu yang dapat memecah konsentrasi remaja pengen-dara (Ragin, 2015).

Myers (2010) mengungkapkan bahwa konformitas dapat mengarahkan indi-vidu pada situasi positif maupun negatif. Konformitas yang mengarahkan pada situasi negatif misalnya adalah ketika remaja ikut untuk berkendara berisiko. Sementara itu, konformitas yang mengarahkan pada situasi positif adalah ketika remaja ikut untuk berkendara aman.

Pilihan untuk melakukan perilaku berkendara berisiko tampaknya melibatkan komponen internal dan eksternal. Salah satu contoh komponen internal perilaku berkendara berisiko adalah regulasi diri. Komponen eksternal yang dapat dilibatkan dalam perilaku berkendara berisiko adalah pengaruh lingkungan. Proses menanggapi pengaruh lingkungan dapat diwujudkan dalam bentuk konformitas. Akan tetapi, kedua proses mental tersebut belum terbuk-ti benar peranannya terhadap perilaku ber-kendara berisiko khususnya pada remaja. Oleh sebab itulah peneliti hendak meneliti adanya peranan regulasi diri dan konformitas terhadap diterapkannya perilaku berkendara berisiko pada remaja. Konformitas yang peneliti jadikan fokus pembahasan adalah konformitas terhadap teman sebaya.

Penelitian terkait perilaku berkendara ini merupakan salah satu kajian terkait psikologi transportasi. Dengan demikian, penelitian ini dapat dijadikan sebagai tambahan kajian dari adanya kontribusi aspek kognitif dan sosial pada fenomena perilaku berlalu lintas di masyarakat. Selain itu, penelitian ini dapat mengimbangi perkembangan iptek di bidang transportasi melalui sudut pandang ilmu psikologi. Harapannya, pesatnya perkembangan teknologi transportasi tidak hanya diim-bangi dengan rencana penatalaksanaan sarana dan prasarana tetapi juga mana-jemen diri individu-individu yang mengg-unakannya. Secara praktis, penelitian ini diharapkan mampu menjadi bahan pertim-bangan untuk memperbaiki penerapan kebijakan terkait sistem transportasi dan lalu lintas yang lebih mengedepankan aspek kesehatan fisik dan psikologis masyarakat khususnya anak dan remaja.

\section{Metode}

Partisipan

Penelitian melibatkan remaja berusia 16 hingga 18 tahun yang memenuhi syarat subjek penelitian. Syarat subjek penelitian ini adalah remaja yang sudah bisa dan biasa mengendarai kendaraan bermotor. Subjek dalam penelitian ini merupakan siswa-siswi SMAN X Kota Magelang.

\section{Instrumen pengukuran}

Skala perilaku berkendara berisiko

Skala perilaku berkendara berisiko pada penelitian ini merupakan skala yang peneliti susun sendiri dengan mengacu pada aspek-aspek perilaku berkendara berisiko menurut Vassallo dkk. (2015); Ramisetty-Mikler dan Almakadma (2016) serta Wishart, Somoray, dan Rowland (2016). Aspek perilaku berkendara berisiko itu antara lain: a) berkendara dengan mengabaikan batas kecepatan; b) Pengendara lengah ketika berkendara; c) pelanggaran terhadap rambu-rambu lalu lintas di persimpangan; dan d) berkendara dalam distraksi. Selain mengacu pada empat aspek itu, peneliti juga menambahkan beberapa aitem yang peneliti adaptasi dari skala perilaku berkendara 
Manchester Driving Behaviour Quetionnaire (DBQ) dalam penelitian Wishart dkk. (2016). Skala perilaku berkendara berisiko terdiri dari 46 aitem sebelum uji coba. Pengujian skala ini menghasilkan koefisien alpha sebesar 0,861 dengan 13 aitem digugurkan. Koefisien korelasi aitem-total pada skala ini bergerak dari 0,252 hingga 0,621 . Koefisien alpha setelah gugur aitem sebesar 0,899 .

\section{Skala regulasi diri}

Skala regulasi diri dalam penelitian ini adalah skala regulasi diri yang diadaptasi dari The Czech Self-Regulation Quetionnaire (SRQ-Cz). SRQ-Cz adalah skala hasil validasi ulang oleh Gavora dkk. (2015) dari skala regulasi diri yang disusun oleh Brown dkk (1999). Adaptasi bahasa pada skala dilakukan dengan bantuan ahli linguistik. Terdapat 27 aitem dalam skala yang berasal dari empat aspek, yaitu kontrol terhadap impuls, orientasi tujuan, self-direction, dan pengambilan keputusan. Pengujian skala regulasi diri menghasilkan koefisien alpha sebesar 0,856 dengan dua aitem digugurkan. Koefisien korelasi aitem-total pada skala ini bergerak dari 0,251 hingga 0,673 . Koefisien alpha setelah gugur aitem sebesar 0,860.

\section{Skala konformitas terhadap teman sebaya}

Skala konformitas terhadap teman sebaya dalam penelitian ini peneliti modifikasi dari skala konformitas terhadap teman sebaya dari Sulartiningsih (2013). Peneliti melakukan modifikasi skala yang berupa pengubahan pilihan respon dan perbaikan bahasa. Peneliti mengubah pilihan respon "ragu-ragu" pada skala milik Sulartiningsih (2013) menjadi pilihan respon "netral". Skala terdiri dari 28 aitem sebelum uji coba yang meliputi tiga aspek berupa: 1) kekompakan; 2) kesepakatan; dan 3) ketaatan. Pengujian skala konformitas terhadap teman sebaya menghasilkan koefisien alpha sebesar 0,769 dengan 11 aitem digugurkan. Koefisien korelasi aitem-total pada skala ini bergerak dari 0,256 hingga 0,660. Koefisien alpha setelah gugur aitem sebesar 0,816 .

Prosedur penelitian

Analisis data penelitian dilakukan dengan menggunakan model analisis regresi berganda. Sebelum melakukan pengujian hipotesis, peneliti melalui tiga macam uji asumsi berupa uji normalitas, uji linieritas, dan uji multikolinieritas. Seluruh bentuk analisis statistik dari tahap uji coba hingga penelitian dilakukan dengan menggunakan program SPSS for Windows version 20 .

\section{Hasil}

Penelitian melibatkan 83 subjek yang memenuhi syarat. Perbandingan besarnya skor hipotetik dengan skor empirik pada penelitian ini menunjukkan bahwa perilaku berkendara berisiko dan konformitas terhadap teman sebaya yang dilakukan oleh subjek tidak setinggi yang diperkirakan. Sementara itu, regulasi diri yang dimiliki subjek lebih tinggi dari yang diperkirakan. Hal itu disebabkan oleh besarnya rerata empirik pada variabel perilaku berkendara berisiko dan variabel konformitas terhadap teman sebaya lebih rendah dari rerata hipotetiknya, sedangkan rerata empirik variabel regulasi diri lebih tinggi dari rerata hipotetiknya. 
Nilai standar deviasi empirik yang lebih rendah dari nilai standar deviasi hipotetik

Tabel 1

Distribusi Skor Hipotetik dan Skor Empirik

\begin{tabular}{|c|c|c|c|c|c|c|c|c|}
\hline \multirow[t]{2}{*}{ Variabel } & \multicolumn{4}{|c|}{ Skor Hipotetik } & \multicolumn{4}{|c|}{ Skor Empirik } \\
\hline & $\begin{array}{c}\mathbf{X}_{\mathbf{m}} \\
\text { in }\end{array}$ & $\begin{array}{l}\mathbf{X}_{\mathbf{m}} \\
\mathrm{ax}\end{array}$ & $\begin{array}{c}\text { Mea } \\
n\end{array}$ & SD & $\begin{array}{c}\mathbf{X}_{\mathbf{m}} \\
\text { in }\end{array}$ & $\begin{array}{c}\mathbf{X}_{\mathrm{m}} \\
\text { ax }\end{array}$ & $\begin{array}{l}M e \\
\text { an }\end{array}$ & SD \\
\hline $\begin{array}{l}\text { Perilaku } \\
\text { Berkendara } \\
\text { Berisiko }\end{array}$ & 33 & $\begin{array}{c}16 \\
5\end{array}$ & 99 & 22 & 48 & 97 & $\begin{array}{c}71,0 \\
4\end{array}$ & $\begin{array}{c}11,3 \\
3\end{array}$ \\
\hline Regulasi Diri & 25 & $\begin{array}{c}12 \\
5\end{array}$ & 75 & $\begin{array}{l}16 \\
67\end{array}$ & 67 & $\begin{array}{l}10 \\
8\end{array}$ & $\begin{array}{c}85,7 \\
6\end{array}$ & 8,29 \\
\hline $\begin{array}{l}\text { Konformitas } \\
\text { terhadap } \\
\text { Teman } \\
\text { Sebaya }\end{array}$ & 17 & 85 & 51 & $\begin{array}{l}11 \\
33\end{array}$ & 37 & 59 & $\begin{array}{c}49,4 \\
5\end{array}$ & 5,31 \\
\hline
\end{tabular}

Keterangan:

Xmin :Skor minimal

$X_{\max } \quad$ :Skor maksimal

Mean : Skor rerata

SD : Standar deviasi

menunjukkan bahwa subjek penelitian cenderung memberikan jawaban yang seragam pada skala penelitian. Distribusi skor hipotetik dan skor empirik dapat dilihat pada Tabel 1.

Data penelitian melalui uji asumsi terlebih dahulu sebelum dapat digunakan untuk menguji hipotesis. Uji asumsi yang digunakan adalah uji normalitas, uji linieritas, dan uji multikolinieritas. Uji asumsi menunjukkan bahwa data penelitian pada tiga skala penelitian ini tersebar secara normal (perhitungan koefisien Kolmorgorov-Sminorv-Z; $p>0,05$ ), prediktor dan kriterium memiliki hubu-ngan yang linier $(p<0,05)$, dan masing-masing prediktor tidak saling berhubungan (tidak terjadi multikolinieritas) (tolerance $<0,10$; VIF > 10).

Uji hipotesis menunjukkan bahwa regulasi diri dan konformitas terhadap teman sebaya berperan bersama-sama secara signifikan terhadap diterapkannya perilaku berkendara berisiko pada remaja
$\left(F=6,219 ; p<0,05 ; R^{2}=0,13\right)$. Besarnya nilai $R^{2}$ menunjukkan bahwa regulasi diri dan konformitas terhadap teman sebaya berkontribusi sebesar 13,5\% diterapkannya perilaku berkendara berisiko. Sementara

Tabel 2

Hasil Uji Parsial

\begin{tabular}{lcc}
\multicolumn{1}{c}{ Variabel } & $t$ & Sig $(p)$ \\
\hline Regulasi Diri * Perilaku & $-2,062$ & 0,043 \\
Berkendara Berisiko & & \\
\hline Konformitas terhadap & 2,173 & 0,033 \\
Teman Sebaya * Perilaku & & \\
Berkendara Berisiko & & \\
\hline *Taraf Signifikansi $p<0,05$ &
\end{tabular}

itu, persentase sisanya $(86,5 \%)$ merupakan besarnya kontribusi variabel lain yang tidak diteliti oleh peneliti, terhadap diterapkannya perilaku berkendara berisiko.

Selanjutnya, hasil uji parsial menunjukkan bahwa korelasi antara regulasi diri dengan perilaku berkendara berisiko memiliki nilai $t$ sebesar $-2,062 \quad(p<0,05)$. Dengan demikian, dapat dikatakan bahwa kedua variabel tersebut berkorelasi secara signifikan. Hal yang sama juga terjadi pada korelasi antara konformitas terhadap teman sebaya dengan perilaku berkendara berisiko. Kedua variabel tersebut memiliki nilai $t$ sebesar $2,173(p<0,05)$, yang menunjukkan bahwa keduanya berkorelasi secara signifikan.

Peneliti mengetahui arah korelasi masing-masing variabel dependen dengan variabel independen melalui tanda minus atau tanpa tanda yang muncul di depan angka koefisien regresi. Analisis statistik menunjukkan variabel regulasi diri berkorelasi negatif dengan perilaku berkendara berisiko $(\beta=-0,305)$. Sebaliknya, perilaku konformitas pada penelitian ini berkorelasi secara positif dengan perilaku berkendara berisiko $(\beta=0,502)$. Sementara itu, sum- 
bangan efektif masing-masing variabel independen merupakan hasil dari perkalian antara nilai beta dengan zero-

Tabel 3

Sumbangan Efektif Variabel Independen

\begin{tabular}{lcclc}
\hline \multirow{2}{*}{ Prediktor } & \multicolumn{5}{c}{ Sumbangan Efektif } \\
\cline { 2 - 5 } & Beta & $\begin{array}{l}\text { Zero- } \\
\text { order }\end{array}$ & $\begin{array}{l}\text { Beta * } \\
\text { Zero- } \\
\text { order }\end{array}$ & Persentase (\%) \\
\hline Regulasi Diri & $-0,223$ & $-0,289$ & 0,065 & 6,5 \\
\hline $\begin{array}{l}\text { Konformitas } \\
\text { terhadap } \\
\text { Teman Sebaya }\end{array}$ & 0,235 & 0,298 & 0,070 & 7 \\
\hline $\begin{array}{l}\text { Catatan: zero } \\
\text { sederhana. }\end{array}$ & & & & \\
\end{tabular}

order. Nilai-nilai perhitungan tersebut terdapat pada Tabel 3.

Analisis tambahan menunjukkan adanya perbedaan yang signifikan pada perilaku berkendara berisiko dan konformitas terhadap teman sebaya antara subjek laki-laki dan perempuan $(t=-0,4660$; dan $t=-$ 3,680; dengan masing-masing nilai $p<0,05$ ). Akan tetapi, tidak ada perbedaan yang signifikan terkait perilaku berkendara berisiko dan pengalaman kecelakaan lalu lintas $(t=0,359 ; \quad p>0,05)$. Tidak adanya perbedaan juga terjadi antara regulasi diri dan pengalaman kecelakaan lalu lintas. Diketahui bahwa tidak terdapat perbedaan regulasi diri antara subjek yang pernah dan belum pernah mengalami kecelakaan lalu lintas $(t=0,195 ; p>0,05)$.

\section{Diskusi}

Tren berkendara di Indonesia tidak hanya dilakukan oleh salah satu gender saja. Oleh sebab itu, potensi untuk berken-dara berisiko pun dimiliki oleh laki-laki maupun perempuan. Dalam penelitian ini peneliti mendapatkan data adanya perbedaan perilaku berkendara berisiko antara remaja laki-laki dan perempuan. Remaja laki-laki pada penelitian ini memiliki nilai rata-rata perilaku berkendara berisiko yang lebih tinggi daripada perempuan, yang mana perbedaan itu sangat signifikan.

Secara berturut-turut, perilaku berkendara berisiko yang banyak dilakukan oleh subjek laki-laki pada penelitian ini adalah berkendara dengan mengabaikan batas kecepatan, berkendara dalam distraksi, lengah ketika berkendara, dan melanggar rambu-rambu lalu lintas. Hal ini terlihat dari besarnya rerata masingmasing aspek perilaku berkendara berisiko pada subjek laki-laki. Aspek berkendara dengan menga-baikan batas kecepatan memiliki mean paling tinggi di antara rerata pada tiga aspek yang lain. Temuan ini selaras dengan penelitian sebelumnya yang mengungkap bahwa mengabaikan batas kecepatan berkendara merupakan perilaku yang banyak dilakukan oleh lakilaki sehingga menjadi penyebab utama kecela-kaan lalu lintas pada kelompok gender tersebut (Rhodes \& Pivik, 2010).

Ketika melakukan aktivitas berlalu lintas seperti berkendara, individu dapat menghadapi pengaruh dan tuntutan dari lingkungan sosialnya. Individu berhadapan dengan peraturan yang memaksa untuk dipatuhi. Akan tetapi, pada saat yang sama, individu juga dapat mengalami dorongan atau tuntutan untuk melewati batas peraturan. Menurut Gavora dkk. (2015) dorongan-dorongan itu dapat dikendalikan apabila individu memiliki regulasi diri yang baik.

Regulasi diri yang baik dapat termanifestasikan dari adanya tujuan yang telah direncanakan dan ingin dicapai oleh individu (Gavora dkk., 2015). Individu dengan regulasi diri yang baik akan melakukan aktivitas-aktivitas pencapaian tujuan yang bersifat positif dan membangun (Baumeister \& Bushman, 2014). Pada penelitian ini, subjek penelitian adalah remaja yang sedang menempuh pendidikan jenjang SMA. Pendidikan, sebagaimana yang disebutkan oleh WHO (2007), adalah 
salah satu aktivitas pengembangan diri yang dilakukan oleh remaja. Aktivitas tersebut disertai dengan tujuan dan targettarget subjektif masing-masing individu. Salah satu hal yang mendukung aktivitas pengembangan diri itu adalah melakukan mobilitas, misalnya dengan berkendara. Berdasarkan penelitian ini, peneliti pun mendapatkan data bahwa $76 \%$ siswa dari empat kelas di SMAN $X$ adalah pelajar yang biasa mengendarai sendiri kendaraannya. Melalui regulasi diri yang dimilikinya, remaja dapat memilih dan memutuskan cara yang tepat untuk mencapai tujuannya, misalnya dengan mengendarai kendara-annya dengan cara yang aman.

Regulasi diri berkaitan erat dengan pilihan dan pengambilan keputusan (Baumeister dkk., 2007). Taylor dkk. (2006) menyatakan bahwa di dalam suatu proses regulasi diri, individu memiliki sistem pengambilan keputusan untuk melakukan atau menghindari sesuatu. Dalam hal perilaku berkendara, regulasi diri memainkan peran untuk mengendalikan pengambilan keputusan berkendara secara aman atau justru berkendara dengan risiko tinggi.

Proses pengambilan keputusan pada aspek regulasi diri dilakukan dengan cara mengendalikan fungsi pikiran, perasaan, dan perilaku (Baumeister dkk., 2007). Akan tetapi, kendali untuk memilih dan memutuskan perilaku mana yang dikehendaki oleh individu tidak luput dari pengaruh individu lain. Hal ini didasari oleh pemahaman bahwa pengambilan keputusan (dalam konsep regulasi diri) tidak jauh terlepas dari perkembangan self itu sendiri, yang mana, self individu dapat berkem-bang apabila individu menjalin interaksi dengan individu lain.

Hal ini selaras dengan penelitian Scott-Parker dkk. (2014). Mereka menjelaskan bahwa ketika berkendara, seorang remaja dapat mencerna, mengingat, meniru, dan atau melakukan perilaku berkendara yang dilakukan oleh orang tua dan teman sebayanya. Bila dikaitkan dengan peraturan atau norma, pengaruh eksternal dapat bernilai positif atau negatif. Pengaruh eksternal yang positif berarti pengaruh yang menguatkan untuk berperilaku secara aman. Sedangkan pengaruh eksternal nega-tif berarti pengaruh yang menguatkan untuk berperilaku berisiko. Ketika remaja memiliki regulasi diri yang baik, remaja dapat memilih untuk berken-dara secara aman karena dirinya sadar (aware) akan pentingnya peraturan itu. Sebaliknya, apabila remaja memiliki kemampuan pengendalian diri yang rendah, remaja dapat cenderung untuk meniru orang lain untuk berkendara berisiko.

Pada penelitian ini, peran pengaruh eksternal pada perilaku berisiko diungkap melalui data dari skala konformitas terhadap teman sebaya. Peneliti memperoleh data bahwa konformitas terhadap teman sebaya menyumbang secara efektif (7\%) dan berkorelasi positif dengan perilaku berkendara berisiko. Korelasi positif pada penelitian ini mengindikasikan bahwa semakin tinggi konformitas yang dimiliki subjek, maka semakin tinggi pula potensi-nya untuk berkendara berisiko. Korelasi positif tersebut menunjukkan bahwa pengaruh sosial berupa konformitas pada konteks penelitian ini mengarahkan subjek pada perilaku yang berkonsekuensi negatif.

Pada kategorisasi subjek penelitian, diketahui bahwa subjek pada penelitian ini merupakan subjek yang berkendara dengan risiko rendah dan sedang. Kategori berken-dara dengan risiko rendah dan sedang tersebut didukung dengan regulasi diri yang menempati posisi sedang dan tinggi serta konformitas yang rendah dan sedang. Dengan demikian, adanya regulasi diri yang sedang dan tinggi serta 
konformitas yang rendah dan sedang dapat mengimbangi perilaku berkendara berisiko yang rendah dan sedang pula.

Regulasi diri juga menyasar pada kemampuan untuk belajar dari pengalaman atau kesalahan di masa lalu (Gavora dkk., 2015). Pada situasi berlalu lintas, individu dapat memiliki berbagai macam pengalaman yang dapat dijadikan pembelajaran. Salah satu pengalaman umum yang banyak terjadi yaitu kecelakaan lalu lintas. Penelitian ini menunjukkan bahwa $48 \%$ subjek penelitian pernah mengalami kecelakaan lalu lintas. Individu yang mampu menjalankan fungsi regulasi dirinya akan memanfaatkan pengalaman itu untuk memperbaiki diri dengan cara mengendalikan dorongan untuk melakukan perilaku berkendara berisiko pada kesempatan yang akan datang. Akan tetapi, bila melihat perbandingan jumlah subjek dengan dan tanpa pengalaman kecelakaan lalu lintas, adanya perbedaan regulasi diri pada kedua kelompok subjek belum tentu terjadi. Hasil uji beda menunjukkan bahwa tidak terdapat perbedaan regulasi diri antara subjek yang pernah dan belum pernah mengalami kecelakaan lalu lintas. Artinya, subjek yang pernah dan belum pernah kecelakaan memiliki kecenderungan regulasi diri yang sama. Hal ini juga terlihat dari sebaran skor empirik seluruh subjek penelitian yang cenderung seragam. Meskipun perbedaan tersebut tidak ada, bukan berarti peran regulasi diri tidak dipentingkan. Terdapat aspek-aspek regulasi diri yang lain yang relevan untuk diterapkan sebagai bahan evaluasi dan intervensi bagi subjek penelitian.

Setiap individu yang menerapkan perilaku berkendara berisiko rentan mengalami kecelakaan lalu lintas. Perilaku berkendara berisiko merupakan sebab, sedangkan kecelakaan lalu lintas adalah akibatnya. Oleh karena itu, peneliti mengajukan hipotesis nol bahwa tidak ada perbedaan perilaku berkendara berisiko bila ditinjau dari ada tidaknya pengalaman kecelakaan lalu lintas. Hipotesis tersebut diterima setelah melalui analisis uji beda. Kelompok subjek yang pernah mengalami kecelakaan lalu lintas memang memiliki nilai rata-rata perilaku berkendara berisiko yang lebih tinggi daripada yang belum pernah kecelakaan. Akan tetapi, perbedaan tersebut relatif kecil dan tidak signifikan. Artinya, remaja pada penelitian ini memiliki potensi berkendara berisiko yang sama aja.

Berdasarkan penelitian Gavora dkk. (2015), regulasi diri berkorelasi negatif dengan perilaku berisiko seperti penyalahgunaan obat, berkendara di bawah pengaruh alkohol, dan merokok. Pada penelitian ini, ternyata korelasi negatif juga terjadi. Berdasarkan analisis statistik yang peneliti lakukan terhadap subjek penelitian, diketahui bahwa regulasi diri berkorelasi negatif dengan perilaku berkendara berisiko. Hal ini mengindikasikan bahwa ketika remaja memiliki regulasi diri yang tinggi, remaja akan lebih rendah kecenderungannya untuk melakukan perilaku berkendara berisiko. Pada penelitian ini, regulasi diri memberikan kontribusinya sebesar 6,5\% terhadap perilaku berkendara berisiko pada remaja subjek penelitian ini.

Pengaruh sosial berkaitan dengan situasi kontrol. Pengaruh sosial dapat menjadi sumber social control dalam suatu kelompok, tetapi dapat juga menjadi sumber perubahan norma dalam kelompok (social change) (Martin \& Hewstone, 2003). Salah satu bentuk pengaruh sosial yang dominan dalam social control, menurut Martin dan Hewstone (2003) adalah konformitas.

Pada penelitian ini, data menunjukkan bahwa subjek memiliki kecenderungan konformitas yang mengarahkan pada perilaku berkendara berisiko. Padahal, perilaku berkendara berisiko merupa- 
kan perilaku melampaui batas peraturan yang telah ditetapkan secara legal. Dengan demikian, konformitas yang dilakukan oleh subjek lambat laun dapat menimbulkan terjadinya perubahan terhadap peraturan atau norma yang ada dalam kelompok, baik kelompok teman sebaya ketika berlalu lintas maupun individuindividu lain yang berlalu lintas. Hal ini dapat menimbulkan kontradiksi, terlebih di daerah tempat penelitian ini dilakukan. Daerah tempat penelitian ini merupakan salah satu daerah yang memperoleh penghargaan terkait sistem tata lalu lintasnya. Kontradiksi dapat timbul apabila individu justru cenderung conform untuk berperilaku berisiko.

Ketika berkendara, individu berpotensi menghadapi situasi lalu lintas yang memicu stress bagi dirinya. Individu tidak hanya mendapatkan respon positif dan menyenangkan dari orang lain (lingkungan lalu lintasnya), tetapi bisa juga mendapatkan respon dan situasi yang negatif. Situasi negatif itu dapat berupa suatu kejadian pelanggaran lalu lintas yang menghambat arus lalu lintas tetapi banyak individu yang melakukannya. Konformitas dapat dilaku-kan oleh individu untuk turut melakukan perilaku melewati batas peraturan itu. Sebab, menurut Franzoi (2009), konfor-mitas dapat dilakukan oleh individu sebagai cara untuk mengurangi stres yang timbul akibat adanya respon negatif dari orang lain. Respon atau situasi negatif tersebut dapat terjadi ketika pengendara berada di persimpangan (traffic light), area putar balik, situasi-situasi lalu lintas padat, dan dapat pula berupa tekanan dari teman sebaya untuk melanggar peraturan kesela-matan. Konformitas untuk taat kepada peraturan legal pun dapat mengendur dan digantikan oleh konformitas untuk berkendara berisiko.
Pada remaja, konformitas cenderung dilakukan terhadap teman sebayanya (Santrock, 2014). Hal ini tidak luput dari penelitian yang menyatakan bahwa pada usia remaja, individu lebih banyak mengalami tekanan dari teman sebayanya (Santrock, 2014; Scott-Parker dkk., 2014). Remaja juga cenderung akan mengidentikkan diri dengan teman-teman dalam kelompoknya (McGhie dkk., 2011; Santrock, 2014).

Tekanan teman sebaya dapat mempengaruhi individu dalam berperilaku di lalu lintas. Scott-Parker dkk (2014) mengemukakan bahwa perilaku remaja ketika berkendara dipengaruhi oleh pengalamannya bersama teman sebaya. Selain menerima informasi dan mempelajari perilaku berkendara dari teman sebaya, remaja juga bisa mendapatkan penguatan dari teman-temannya untuk berkendara berisiko. Terkait dengan perbedaan gender, telah diungkap sebelumnya oleh ScottParker dkk. (2014) bahwa remaja laki-laki menerima tekanan yang lebih besar daripada perempuan. Oleh sebab itu, remaja laki-laki akan cenderung conform dengan teman sebayanya. Pada penelitian ini juga terlihat dari nilai rata-rata konformitas kelompok subjek laki-laki dan perempuan. Analisis statistik memperlihatkan bahwa kelompok subjek laki-laki memiliki nilai rata-rata konformitas yang lebih besar daripada kelompok subjek perempuan. Nilai signifikansi sebesar 0,000 menunjukkan bahwa perbedaan tersebut sangat signifikan.

Keberadaan teman sebaya tidak hanya dinilai sebagai sumber pengaruh dan social pressure bagi remaja. Menurut Ragin (2015), keberadaan teman sebaya pun dapat menjadi distraktorketika berkendara. Bentuk distraksi itu misalnya bergurau ketika berkendara serta menggunakan teknologi komunikasi yang dapat merusak konsentrasi remaja pengendara. 
Aspek pengendara yang lengah ketika berkendara dapat mencerminkan situasi tersebut. Berdasarkan nilai rerata yang diperoleh 83 subjek penelitian, aspek kelengahan menjadi aspek ketiga yang mampu menunjukkan perilaku berkendara berisiko. Sementara itu, pada subjek lakilaki, berkendara dalam distraksi merupakan aspek kedua yang paling banyak dilakukan.

Peneliti menemukan benang merah bahwa perilaku berkendara melibatkan fungsi regulasi diri dan konformitas. Konformitas sebagai salah satu bentuk dari pengaruh sosial dapat menimbulkan dorongan-dorongan bagi individu untuk berperilaku. Dorongan-dorongan tersebut dapat bernilai positif (adaptif), tetapi dapat juga bernilai negatif (destruktif). Dorongan-dorongan negatif yang diperoleh individu perlu dikendalikan dan dievaluasi oleh individu itu sendiri. Pengendalian dan evaluasi itu dilakukan agar individu dapat mengembangkan perilakunya ke arah yang positif dan menguntungkan bagi pencapaian tujuan pribadinya. Dengan demikian, dapat dikatakan bahwa perilaku berkendara berisiko dapat dikurangi atau dicegah melalui suatu manajemen regulasi diri terhadap pengaruh-pengaruh eksternal yang mungkin diperoleh individu.

\section{Kesimpulan}

Hasil penelitian menunjukkan bahwa regulasi diri dan konformitas, khususnya konformitas terhadap teman sebaya merupakan dua faktor psikologis yang berperan dalam munculnya perilaku berkendara berisiko pada remaja. Regulasi diri dan konformitas memberikan perannya sebesar $13,5 \%$. Kontribusi sebesar $6,5 \%$ diperoleh dari regulasi diri dan $7 \%$-nya adalah kontribusi dari konformitas terhadap teman sebaya.
Terkait dengan hubungannya, regulasi diri berhubungan negatif dengan perilaku berkendara berisiko pada remaja. Adanya peningkatan regulasi diri akan menurunkan perilaku berkendara berisiko. Sebaliknya, ketika regulasi diri itu menurun atau rendah, maka perilaku berkendara berisikonya akan meningkat atau tinggi.

Sementara itu, konformitas terhadap teman sebaya berhubungan positif dengan perilaku berkendara berisiko. Adanya peningkatan perilaku konformitas terhadap teman sebaya (konformitas tinggi) akan turut meningkatkan perilaku berkendara berisiko pada remaja (perilaku berkendara berisiko tinggi). Begitu pula sebaliknya, penurunan konformitas terhadap teman sebaya juga akan menurunkan perilaku berkendara berisiko pada remaja.

Konformitas dalam penelitian ini mengarahkan subjek pada perilaku yang berkonsekuensi negatif. Regulasi diri sebagai proses kendali internal dapat menjalankan fungsinya untuk mengendalikan pengaruh eksternal yang termanifestasikan dalam konformitas tersebut. Oleh sebab itu, keduanya dapat menjadi faktor psikologis yang berperan bersama atas terjadinya perilaku berkendara berisiko.

Analisis tambahan menunjukkan adanya perbedaan gender dalam perilaku berkendara berisiko dan konformitas terhadap teman sebaya. Subjek laki-laki memiliki perilaku berkendara berisiko dan konformitas terhadap teman sebaya yang lebih tinggi daripada perempuan. Sebesar $48 \%$ subjek pernah mengalami kecelakaan lalu lintas. Akan tetapi, tidak terdapat perbedaan yang signifikan antara ada atau tidaknya pengalaman kecelakaan lalu lintas dengan perilaku berkendara berisiko dan regulasi diri.

\section{Saran}


Bagi subjek penelitian, perilaku berkendara berisiko merupakan perilaku yang tidak hanya berpotensi melanggar peraturan, tetapi juga dapat menyebabkan kerugian bagi diri sendiri dan orang lain. Cedera fisik dan kematian karena kecelakaan lalu lintas dapat ditimbulkan oleh penerapan perilaku berkendara berisiko. Oleh sebab itu, penerapan perilaku tersebut perlu diku-rangi atau bahkan dicegah sama sekali. Cara yang bisa dilakukan misalnya dengan mengevaluasi dan meninjau kembali tuju-an penggunaan kendaraan bermotor. Pengalaman-pengalaman negatif yang diperoleh ketika berkendara sebaiknya dijadikan pembelajaran agar dapat lebih sadar akan pentingnya berperilaku aman. Individu juga akan lebih baik untuk mengendalikan masuknya pengaruh negatif dari lingkungan berkendara. Bersa-ma dengan teman sebaya, setiap individu bisa saling mengingatkan dan mendukung satu sama lain untuk membiasakan dan membudayakan perilaku berkendara yang aman.

Bagi sekolah, kasus kecelakaan lalu lintas pada siswa yang berulang setiap tahunnya hendaknya dapat dijadikan bahan untuk memberikan edukasi tentang perilaku berkendara. Edukasi tidak hanya dilaku-kan melalui kerja sama dengan dinas per-hubungan atau kepolisian, tetapi bisa juga melalui cara-cara kreatif yang melibatkan siswa secara langsung. Sekolah dapat mengupayakan promosi atau kampanye bagi siswa/i-nya untuk melakukan self-management dalam rangka membiasakan hidup sehat dan aman.

Bagi peneliti selanjutnya, masih terdapat berbagai macam permasalahan lalu lintas yang dapat ditinjau melalui sudut pandang psikologi transportasi. Temuan-temuan yang ada dalam penelitian ini dapat dijadikan sebagai bahan untuk mengembangkan pengkajian yang lebih mendalam. Akan lebih bermanfaat lagi apabila temuan-temuan yang ada dapat dijadikan sebagai bahan penelitian untuk merumuskan intervensi yang tepat.

\section{Kepustakaan}

Baumeister, R. F., \& Bushman, B. J. (2014). Social psychology and human nature (3rd ed.). Canada: Wadsworth Cengage Learning.

Baumeister, R., Schmeichel, B. J., \& Vohs, K. D. (2007). Self-regulation and executive function: The self as controlling agent. Dalam A. W. Kruglanski, \& E. T. Higgins (Penyunt.), Social psychology: Handbook of basic principles (2nd ed., hal. 516-536). New York: The Guliford Press.

Berger, A. (2011). Self-regulation: Brain, cognition, and development. London: APA.

Briem, V., Radeborg, K., Salo, I., \& Bengston, H. (2004). Developmental aspects of children's behavior and safety while cycling. Journal of Pediatric Psychology, 29, 369-377. doi: 10.1093/jpepsy/jsh040

Franzoi, S. L. (2009). Social psychology (5th ed.). New York: McGraw Hill.

Gavora, P., Jakešova, J., \& Kalenda, J. (2015). The Czech validation of the self-regulation quetionnaire. ProcediaSocial and Behavioral Sciences, 222-230. doi:10.1016/j. Sbspro.2015.01.113

Martin, R., \& Hewstone, M. (2003). Socialinfluence processes of control and change: conformity, obedience to authority and innovation. Dalam M. A. Hogg, \& J. Cooper (Penyunt.), The Sage Handbook of Social Psychology (hal. 266-284). London: Sage.

McGhie, A., Lewis, I., \& Hyde, M. K. (2011). The influence of conformity and group identity on drink walking intentions: Comparing intentions to 
drink walk across risky pedestrian crossing scenarios. Accident Analysis and Prevention, 45, 639-645. doi:10.1016/j. Aap.2011.09.035

Myers, D. G. (2010). Social psychology (10th ed.). New York: McGraw-Hill.

Ragin, D. F. (2015). Health psychology: an interdisciplinary approach to health (2nd ed.). New York: Routledge.

Ramisetty-Mikler, S., \& Almakadma, A. (2016). attitudes and behaviors towards risky driving among adolescents in Saudi Arabia. International Journal of Pediatrics and Adolescent Medicine, 55-63. doi:10.1016/j. Ijpam.2016.03.003

Rhodes, N., \& Pivik, K. (2010). Age and gender differences in risky driving: the roles of positive affect and risk perception. Accident Analysis and Prevention, 923-931. doi:10.1016/j. Aap.2010.11.015

Santrock, J. W. (2014). A topical approach of life span developement (7th ed.). New York: McGraw Hills.

Scott-Parker, B., Watson, B., King, M., \& Hyde, M. (2014). "I would have lost the respect of my friends and family if they knew I had bent the road rules": parents, peers, and the perilous behaviour of young drivers. Transportation Research Part F, 1-13. doi:10.1016/j. Trf.2014.10.004

Sulartiningsih. (2013). Hubungan konsep diri dan konformitas terhadap Kelompok teman sebaya dengan perilaku merokok pada remaja Sekolah Menengah Pertama $(S M P)$. (Tesis tidak dipublikasikan). Fakultas Psikologi Universitas Gadjah Mada, Yogyakarta

Taylor, S. E., Peplau, L. A., \& Sears, D. O. (2006). Social psychology (12th ed.). New Jersey: Pearson Education Inc.

Toroyan, T. (2015). Global status report on road safety 2015. Italy: World Health Organization.
Toroyan, T., \& Peden, M. (2007). Youth and road safety. Geneva: World Health Organization.

Vassallo, S., Lahausse, J., \& Edwards, B. (2015). Factors affecting stability and change in risky driving from late adolescence to the late twenties. Accident Analysis and Prevention, 7787. doi:10.1016/j. Aap.2015.12.010

WHO. (2007). Youth and road safety. Geneva: World Health Organization.

WHO. (2009). Global status report on road safety: time for action. Geneva: World Health Organization.

Wishart, D., Somoray, K., \& Rowland, B. (2016). Role of thrill and adventure seeking in risky work-related driving behaviours. Personality and Individual Differences, 104, 362-367. doi:10.1016/j. Paid.2016.08.033 